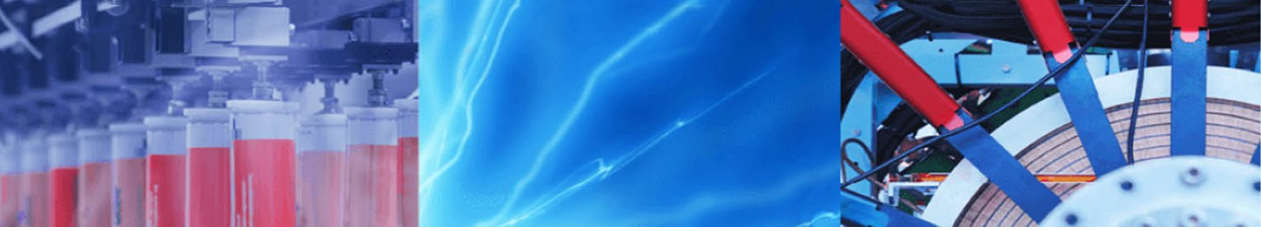

Research Article

\title{
Living with floods through geospatial approach: a case study of Arambag C.D. Block of Hugli District, West Bengal, India
}

\author{
Biswajit Das $^{1} \cdot$ Subodh Chandra Pal ${ }^{1} \cdot$ Sadhan Malik ${ }^{1} \cdot$ Rabin Chakrabortty $^{1}$
}

(c) Springer Nature Switzerland AG 2019

\begin{abstract}
Arambag community development block (C.D. Block) is situated in the interfluvial zone of Damodar and Dwarkeswar River, which is one of the flood-prone areas of West Bengal. Despite the frequent flood problems, population of this region is very high due to the fertile floodplains, on which people are dependent for their livelihood. During the floods, people generally take shelter in nearby safe places, where they can find food, health assistance and safety. School, government buildings, community halls generally act as evacuation shelters due to its limited use. Present study aims to identify the optimal location of shelters during the flood hazards through geospatial techniques. Several factors are analyzed through the analytical hierarchy process to identify their relative importance, finally overlay analysis is done in the geospatial environment to find out the proper locations. Various sites have been identified, out of which most suitable locations have been proposed after the field verification.
\end{abstract}

Keywords Flood $\cdot$ Shelter site $\cdot$ Arambag $\cdot$ GIS

\section{Introduction}

Floods are one of the most frequent and destructive natural disasters in tropical and sub-tropical countries [1-3]. Impact of floods in regard to the socio-economic losses is increasing with the passage of time [4]. In the period of 2000-2011, floods have resulted in economic damages of more than US\$285 billion around the world [5]. Number of deaths related to floods is higher in developing countries and most of them are from low and middle income group $[4,6]$. Several flood control measures have been taken to control the floods, but the intensity and damages remains unchanged [7]. Flood happens over a large part of India during the monsoon season and people lives in the fertile floodplains suffer the most. On an average, in India, flood affects 32 million people per year [8]. Nowadays, governments invest lots of money for disaster management, but the casualty rate and damages are still high due to low efficiency and lack of timeliness. Primary task of any disaster management is to identify the victims, rescue them and providing shelters, food, water and medical care. Preparation, response, recovery and mitigation - these are the cyclic steps of disaster management [9]. Proper preparedness and timely responding helps in the rescue process.

Shelter is considered as a basic requirement by the international human rights, humanitarian and refugee law to protect the disaster affected people [10]. Shelter provides safety, protects from climatic disturbances, and also it is important for survival with dignity [11]. Homes of the affected people can be severally damaged or destroyed during the disaster like flood, so it is necessary to provide them with essential needs for maintaining life [12]. Temporary shelters serve as the basis for shifting the evacuated people in the emergency operation. Existing infrastructure such as schools, clubs, community halls generally serves as the temporary shelters in developing countries like India [10]. These types of public places serve as dual use shelters during the floods because of the limited use and cost

Subodh Chandra Pal, geo.subodh@gmail.com; Biswajit Das, biswajitdas1119@gmail.com; Sadhan Malik, sadhanmalik06@gmail.com; Rabin Chakrabortty, rabingeo8@gmail.com | 'Department of Geography, The University of Burdwan, Burdwan, West Bengal 713104, India.

SN Applied Sciences (2019) 1:329 | https://doi.org/10.1007/s42452-019-0345-3 
effectiveness [13]. But these dual use shelters hamper the primary activities of these places.

The planning of shelters is a complex issue as numerous factors are related with this [14]. Another major problem is to estimate the capacity of the shelters and distribute the evacuees accordingly [15]. Identification of suitable shelter locations and providing basic amenities are necessary for ensuring the effected people with better living conditions. Arambag community development block is very much prone to floods. Despite the frequent floods, no concrete measures have been taken for building flood shelters, which could help immensely during the hazardous condition. The focus of this study is to identify the ideal locations for flood shelters with the help of remote sensing and geographic information system.

\section{Study area}

Arambag is one of the most vulnerable blocks to floods $[16,17]$. Arambag is situated in the interfluvial zone of Dwarkeswar and Damodar river (Fig. 1). Mundeswari-a distributary of Damodar flows through the block. Flood happens in almost every year as discharge exceeds the carrying capacity of these rivers due to the heavy downpours during the monsoon season. It is a low lying floodplain region with fertile soil, which is helpful for agricultural production. Favorable environmental setting makes this region highly populated.

\section{Methodology}

Integrated Geographic Information System (GIS) and Multi-criteria Decision Analysis (MCDA) techniques have been used for setting up the flood shelters. This inter-linking concept is very much useful for tackling decision problems to manage real-world situations [18]. MCDA presents theoretical base for complex decision making process and helps to increase the capability of GIS to deal with spatial problems correctly. MCDA offers wide range of methods which provides meaningful results for spatial decision problems. Analytical Hierarchy Process (AHP) [19] provides flexible decision making tool by pair-wise comparison matrix for structuring the decision problems in hierarchical order. Priorities are given to a theme or sub-theme in 1-9 scale values with respect to a pair of criteria (Table 1). The pair-wise comparisons are structured into a matrix, $C=\left[C_{k p}\right]_{n * n}$ where $C_{k p}$ is the priority of the pair-wise comparison for the $k$-th and $p$-th criteria. Ultimately a vector

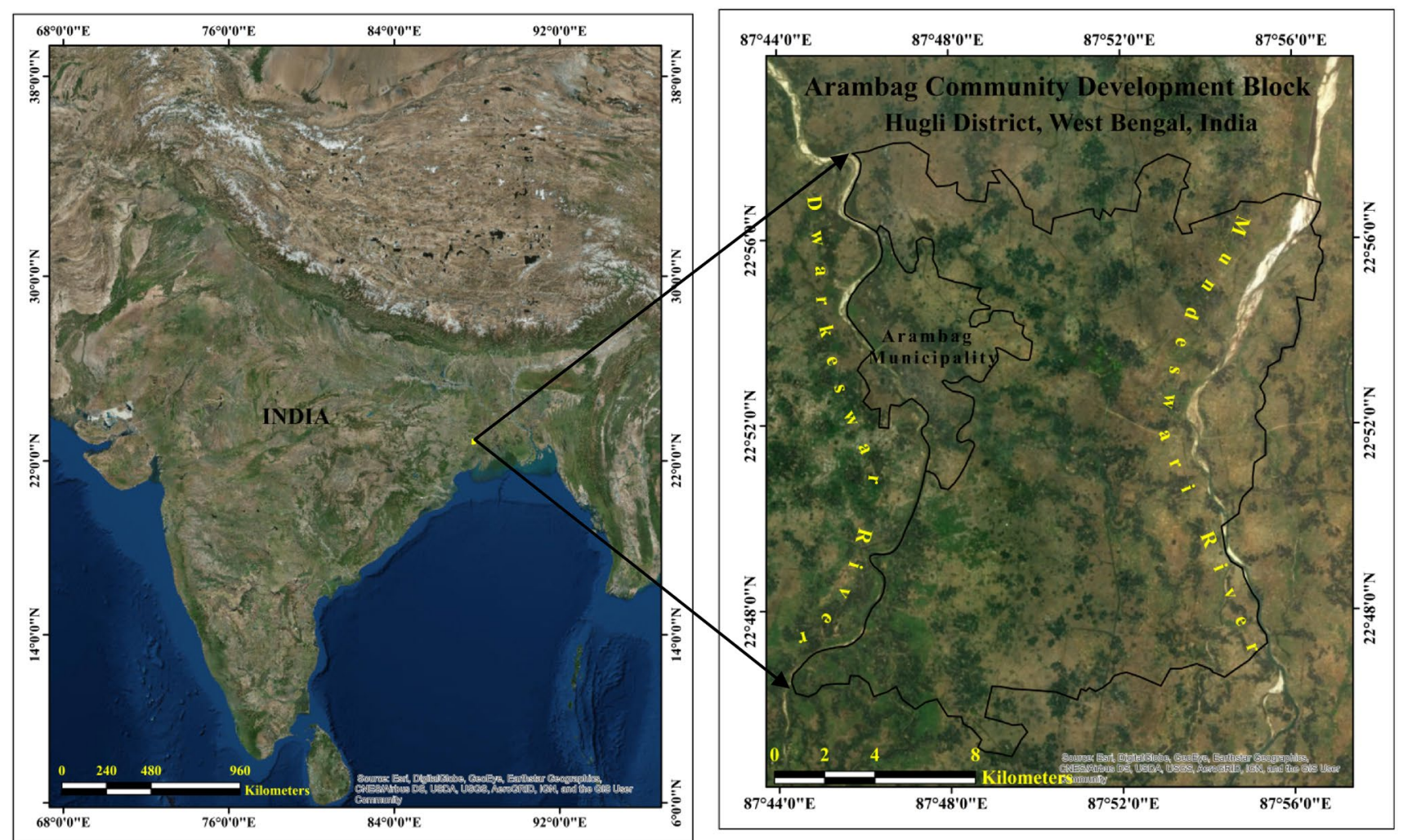

Fig. 1 Google earth view of the study area

\section{SN Applied Sciences}


Table 1 Saaty's scale for prioritizing theme/class in pair-wise comparison

\begin{tabular}{llllll}
\hline $\begin{array}{l}\text { Impor- } \\
\text { tance }\end{array}$ & $\begin{array}{l}\text { Equal } \\
\text { impor- } \\
\text { tance }\end{array}$ & $\begin{array}{l}\text { Moderate } \\
\text { impor- } \\
\text { tance }\end{array}$ & $\begin{array}{l}\text { Strong } \\
\text { impor- } \\
\text { tance }\end{array}$ & $\begin{array}{l}\text { Very } \\
\text { strong } \\
\text { impor- } \\
\text { tance }\end{array}$ & $\begin{array}{l}\text { Extreme } \\
\text { impor- } \\
\text { tance }\end{array}$ \\
\hline Value & 1 & 3 & 5 & 7 & 9 \\
\hline
\end{tabular}

of criterion weights, $w=\left[w_{1}, w_{2}, \ldots, w_{n}\right]$ are obtained from the pair-wise comparison matrix. The weights are attained from the equation, $C_{w}=\lambda_{\max } w$ where $\lambda_{\max }$ is the largest eigen value of $C[18,19]$. According to Saaty [16] consistency ratio of less than 0.10 or $10 \%$ signify a reasonable level of consistency in the pair-wise comparison matrix. The pair-wise comparison technique of AHP is the most extensively used in MCDA-GIS applications for site selection problems, suitability analysis $[20,21]$. Weighted overlay analysis has been performed in the geospatial environment to identify the suitable locations and the result has been verified by the continuous field visit (Fig. 2).

\section{Results and discussion}

\subsection{Controlling factors}

It is very difficult to identify proper locations for shelters as there is no distinct methodology or software to find the optimal solution [14]. Planning of temporary shelters may lead to numerous influencing factors, because it is hard to find any universal rules regarding this $[22,23]$. Physical as well as social factors influence the suitability of flood shelter. These factors vary from one region to another based on the local environment. Location of a shelter depends upon its elevation, accessibility, distance from the flood zones, proximity to settlements, health centers, safety etc.

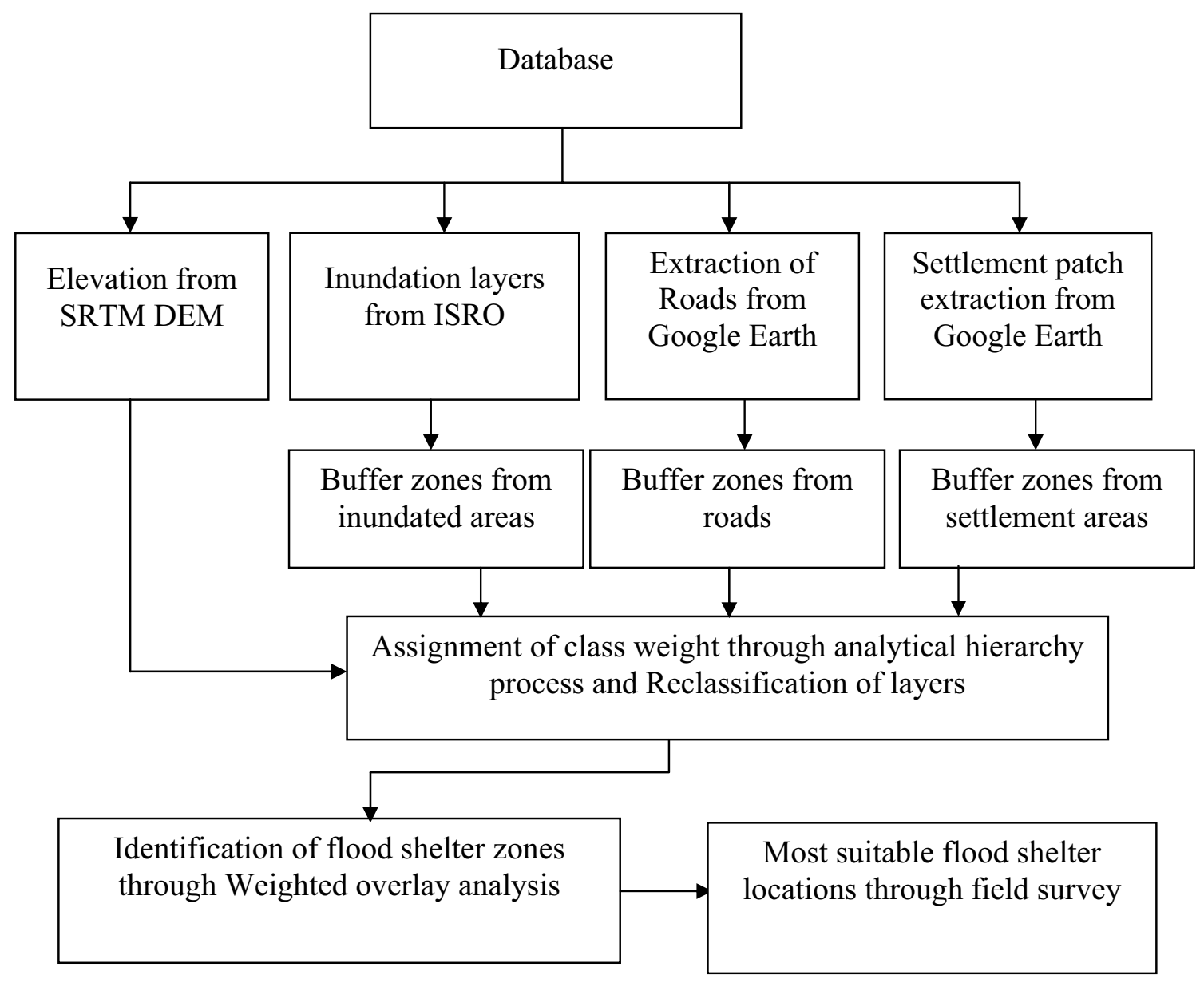

Fig. 2 Methodological framework 


\subsubsection{Distance from inundated zone}

The location of shelters should consider the inundation zone of devastating floods because they should be ideally located outside the flood zones. Inundation layers of major flooded years have been taken to identify the inundated areas as it will represent the maximum areas under inundation which is necessary for setting up shelters. Inundation layers of recent floods during 2015 and 2017 have been taken from the Indian Space Research Organisation's geoportal service to delimit the flood zone. Inundated areas for previous devastating floods have been identified from the discussions with the local disaster management cell and local people.

Buffer zones have been drawn with 200, 500, 1000 and $2000 \mathrm{~m}$ distance from the inundated areas to identify the nearby safe places (Fig. 3). Pair-wise comparison matrix has been done to assign the weights for each buffer zone. Importance has been given to each class as per the conversation with the local people during the field.

Buffer zone of $500 \mathrm{~m}$ from the inundated areas has the highest priority for shelter locations (Table 2). It has the higher priority over $200 \mathrm{~m}$ buffer zone as people do not prefers to stay close to the flooded zone because of the risk of further inundation and other health issues. Priority percentage for the classes of $1000 \mathrm{~m}$ and beyond has decreased due to the fact that the most of the inundated areas are overlapped with the settlement sites and people does not prefer to stay beyond a considerable limit from their habitat. Consistency ratio of the pair-wise
Fig. 3 Buffer zones of inundated areas in Arambag C.D. Block

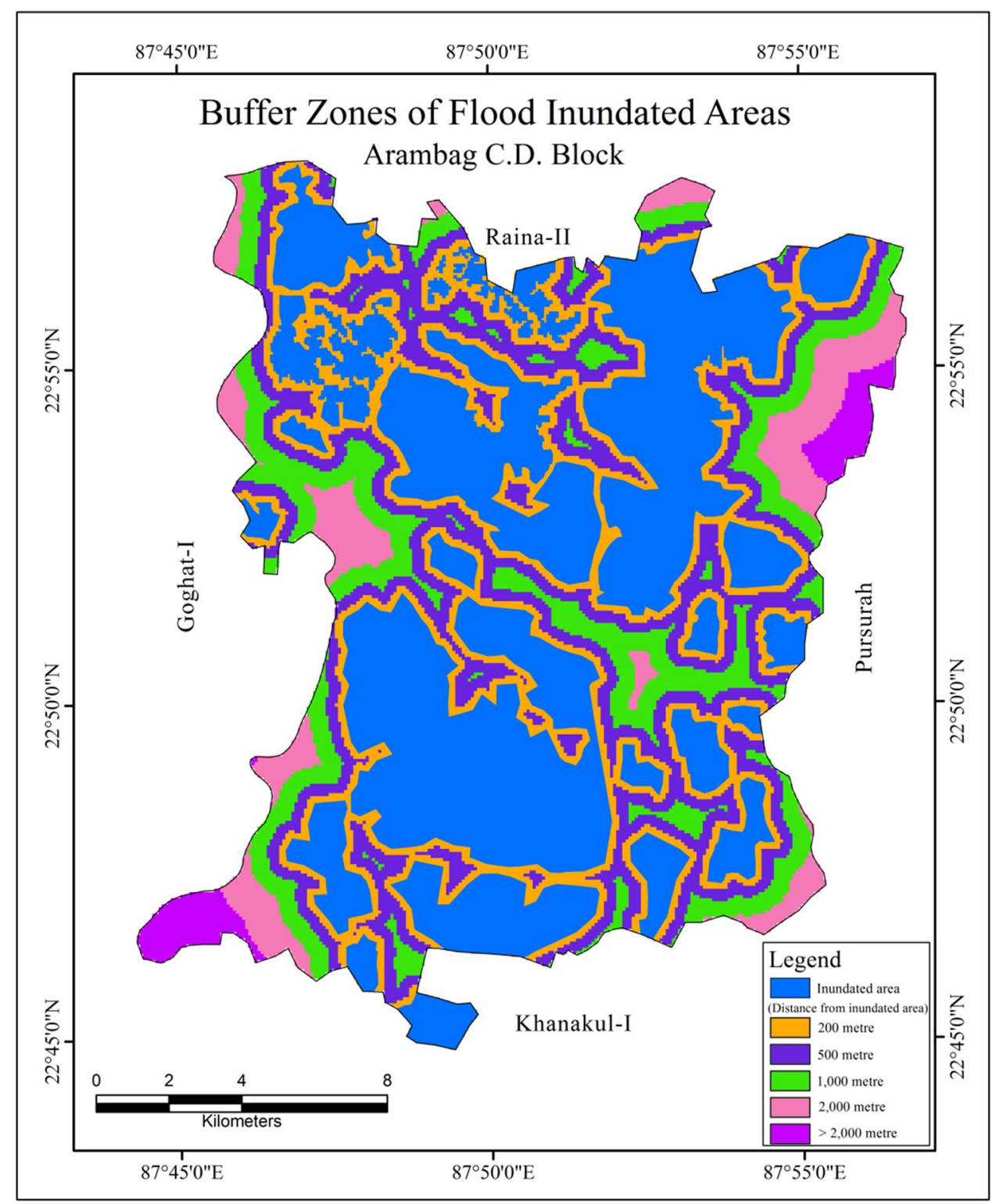


Table 2 Pair-wise comparison matrix for ranking the buffer zones of inundated areas

\begin{tabular}{llllllll}
\hline $\begin{array}{l}\text { Class (distance from } \\
\text { inundated areas) }\end{array}$ & $200 \mathrm{~m}$ & $500 \mathrm{~m}$ & $1000 \mathrm{~m}$ & $2000 \mathrm{~m}$ & $>2000 \mathrm{~m}$ & Priority & Rank \\
\hline $200 \mathrm{~m}$ & 1.00 & 0.25 & 0.33 & 3.00 & 5.00 & 14.50 & 3 \\
$500 \mathrm{~m}$ & 4.00 & 1.00 & 3.00 & 6.00 & 8.00 & 49.00 & 1 \\
$1000 \mathrm{~m}$ & 3.00 & 0.33 & 1.00 & 4.00 & 5.00 & 25.40 & 2 \\
$2000 \mathrm{~m}$ & 0.33 & 0.17 & 0.25 & 1.00 & 3.00 & 7.30 & 4 \\
$>2000 \mathrm{~m}$ & 0.20 & 0.12 & 0.20 & 0.33 & 1.00 & 3.90 & 5 \\
\hline
\end{tabular}

comparison (Table 2) is 5.9\%, which is under the permitted limit.

\subsubsection{Elevation}

Altitude is one of the major influencing factors behind the location of shelters. Relatively high elevated areas are safe from the inundation during a massive flood. The study area belongs to flat plain region where elevation of the land does not vary drastically from one part to another. Digital Elevation Model (DEM) data has been used to identify the relatively elevated areas which are free from inundation.

Digital Elevation Model has been used after processing by fill method to minimize the error. Low lying areas $(<25 \mathrm{~m})$ are mainly found in the eastern and southern part whereas relatively elevated areas are found in the north-western part (Fig. 4). Temporary shelters are generally built over the relatively elevated lands which are scattered in the region. Consistency ratio of the given priority is $5.6 \%$ (Table 3 ). Highest priority is given to the maximum elevated zone as this zone has the minimum chance for inundation. Elevation of 30-35 $\mathrm{m}$ also has high priority as this zone is safe from the inundation. Elevation zone of less than $25 \mathrm{~m}$ is mostly inundated during the flood period so it has the least priority.

\subsubsection{Accessibility to road networks}

Accessibility to the shelter site is one of the primary requisite for the arrival of the affected people as well as successful delivery of relief materials. Timely delivery of relief materials is essential for the successful management of any disaster. Availability of good road connectivity favors a location for shelter site because it has the advantage to access schools, markets, healthcare and other supportive services. Lack of physical accessibility hampers the distribution of emergency aid and destroys the suitability of the shelter site.

Buffer zones have been identified with 100, 200, 500 and $1000 \mathrm{~m}$ distance from the major roads (Fig. 5). Breakdown of the transportation and communication network is the main factor behind the inaccessibility to the interior part during the flood period. Buffer zone of $100 \mathrm{~m}$ distance from major roads have been given maximum priority as people prefers to live in the shelters which are situated along the major roads or highways as there are utmost probability of getting the relief materials. Consistency ratio of the pair-wise comparison matrix is $8.3 \%$ (Table 4), which is under the considerable limit.

\subsubsection{Proximity to settlement sites}

Shelter sites should be located near the affected settlements to facilitate the concerned people to reach the location in minimum time. Shelters nearer to the settlement sites provide maximum chance to the people to evacuate with their valuable items. Majority of the people opts for the nearby available shelters as it is very much difficult to move far with their belongings, domestic animals etc.

Buffer zones have been demarcated with 200, 500, 1000 and $2000 \mathrm{~m}$ from the settlement patches (Fig. 6). Buffer zones within 200 and $500 \mathrm{~m}$ from the settlement sites has the advantage for setting up the shelters as their location is nearer to the built-up area whereas it is not so much suitable beyond $500 \mathrm{~m}$ because of the people's preference to live near their original settlement. It gives them the opportunity to access the home more easily during the post flood event, which helps them to rebuild their house more easily. Buffer zone of $200 \mathrm{~m}$ has been given the maximum priority as it is closest to the settlement sites and priority percentage decreases as the distance increases from the settlement sites (Table 5). Consistency ratio of the pair-wise comparison matrix is $9.3 \%$.

\subsection{Identification of suitable location for shelters}

Identification of the suitable locations for flood shelters has been done through systematic procedure followed by the AHP technique which has the advantage of working with multiple criteria. Assignments of weights are the most difficult and controversial part for this type of work. However AHP has the flexibility as the priority is given to each theme after analyzing it with all the other themes through pair-wise comparison matrix and the priorities can be taken if the consistency ratio remains under $10 \%$. Four criteria have been used in this study to demarcate 
Fig. 4 Elevation map of Arambag C.D. Block

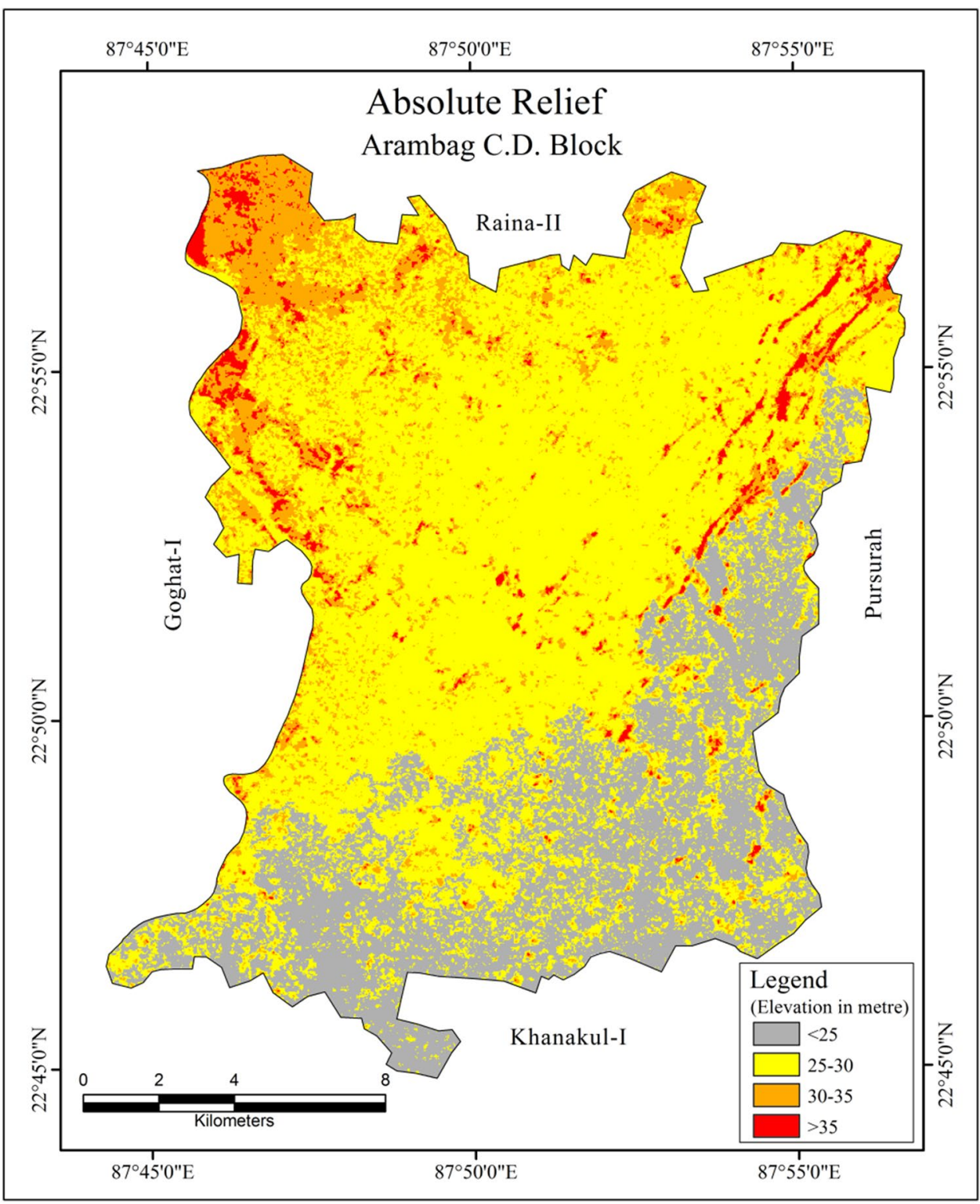

\begin{tabular}{lllllll}
\hline Class & $<25 \mathrm{~m}$ & $25-30 \mathrm{~m}$ & $30-35 \mathrm{~m}$ & $>35 \mathrm{~m}$ & Priority & Rank \\
\hline$<25 \mathrm{~m}$ & 1.00 & 0.20 & 0.17 & 0.14 & 4.80 & 4 \\
$25-30 \mathrm{~m}$ & 5.00 & 1.00 & 0.33 & 0.25 & 14.80 & 3 \\
$30-35 \mathrm{~m}$ & 6.00 & 3.00 & 1.00 & 0.50 & 31.10 & 2 \\
$>35 \mathrm{~m}$ & 7.00 & 4.00 & 2.00 & 1.00 & 49.30 & 1 \\
\hline
\end{tabular}

Table 3 Pair-wise comparison matrix for ranking the elevation zones the suitable locations for flood shelters. There are numerous factors which influences in the location of a shelter. According to the local people's perception, these four factors are mostly important behind the position of temporary shelters over this region.

Among the four factors, distance from the inundated zone gets the maximum priority as it is desirable to locate the shelters in a safe distance from the flooded zone.
Elevated zones are the places where shelters are built as these areas have the minimum chance to get inundated, so it gets the next higher priority. Proximity to settlement sites gets slightly higher priority than the accessibility to road networks due to the fact that evacuation and distribution of the affected people to safe places are the primary task during a disaster like flood and then there is the need to supply the relief materials. Inhabitants of the 
Fig. 5 Buffer zones from the major roads

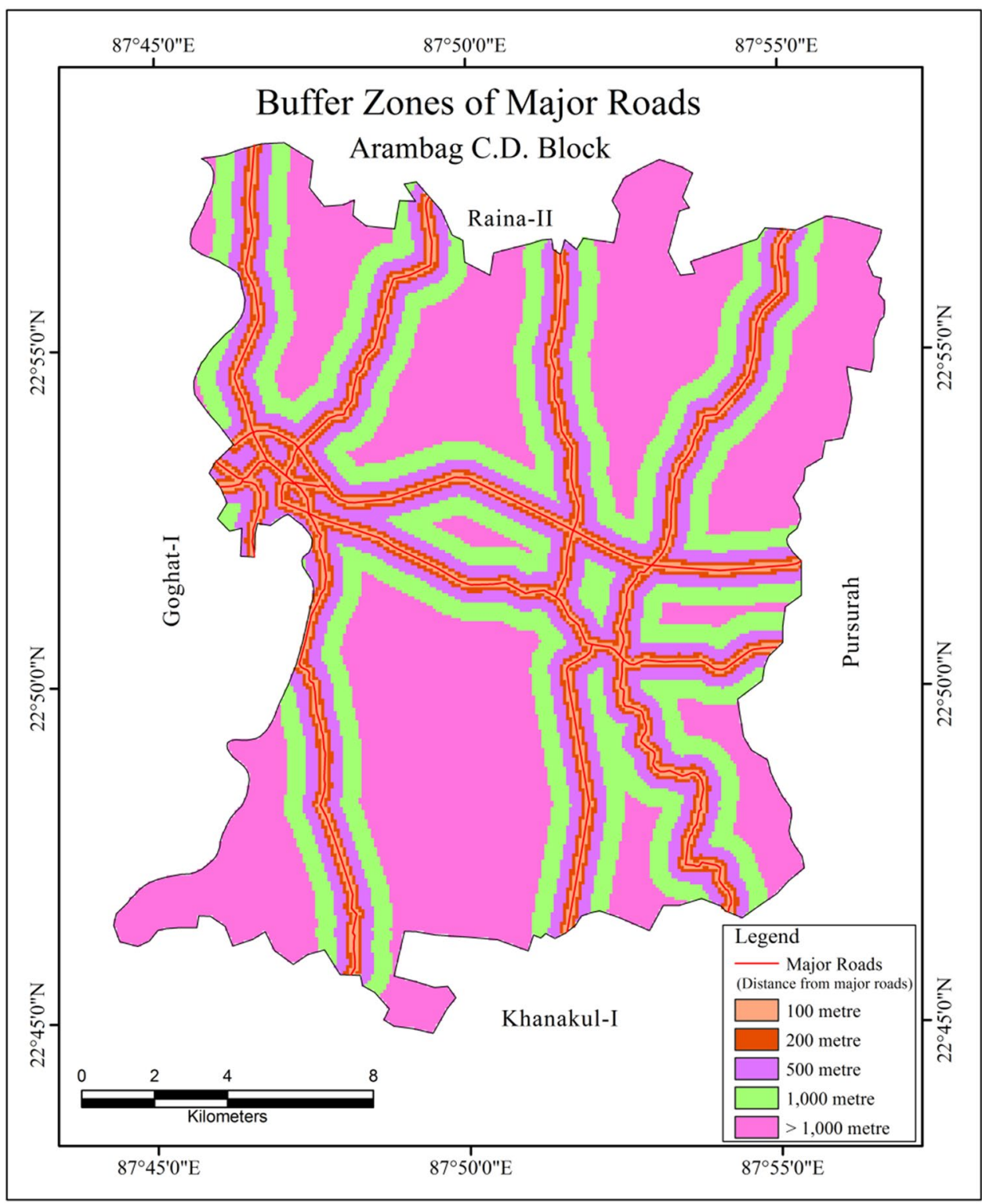

\begin{tabular}{llllllll}
\hline $\begin{array}{l}\text { Class (buffer zones } \\
\text { from roads) }\end{array}$ & $100 \mathrm{~m}$ & $200 \mathrm{~m}$ & $500 \mathrm{~m}$ & $1000 \mathrm{~m}$ & $>1000 \mathrm{~m}$ & Priority & Rank \\
\hline $100 \mathrm{~m}$ & 1.00 & 3.00 & 4.00 & 8.00 & 9.00 & 48.10 & 1 \\
$200 \mathrm{~m}$ & 0.33 & 1.00 & 4.00 & 6.00 & 9.00 & 29.50 & 2 \\
$500 \mathrm{~m}$ & 0.25 & 0.25 & 1.00 & 5.00 & 8.00 & 14.90 & 3 \\
$1000 \mathrm{~m}$ & 0.12 & 0.17 & 0.20 & 1.00 & 2.00 & 4.50 & 4 \\
$>1000 \mathrm{~m}$ & 0.11 & 0.11 & 0.12 & 0.50 & 1.00 & 2.90 & 5 \\
\hline
\end{tabular}

Table 4 Pair-wise comparison matrix for prioritizing the buffer zones of Major roads
Suitable zones for flood shelters have been identified through the analysis of influential factors by AHP and weighted overlay analysis. The study area has been classified into not suitable, least suitable, moderately suitable and highly suitable zones as per the location of flood shelters are concerned (Fig. 7). This categorization (Table 6) which is under the considerable limit of $10 \%$. 
Fig. 6 Buffer zones from the settlement sites

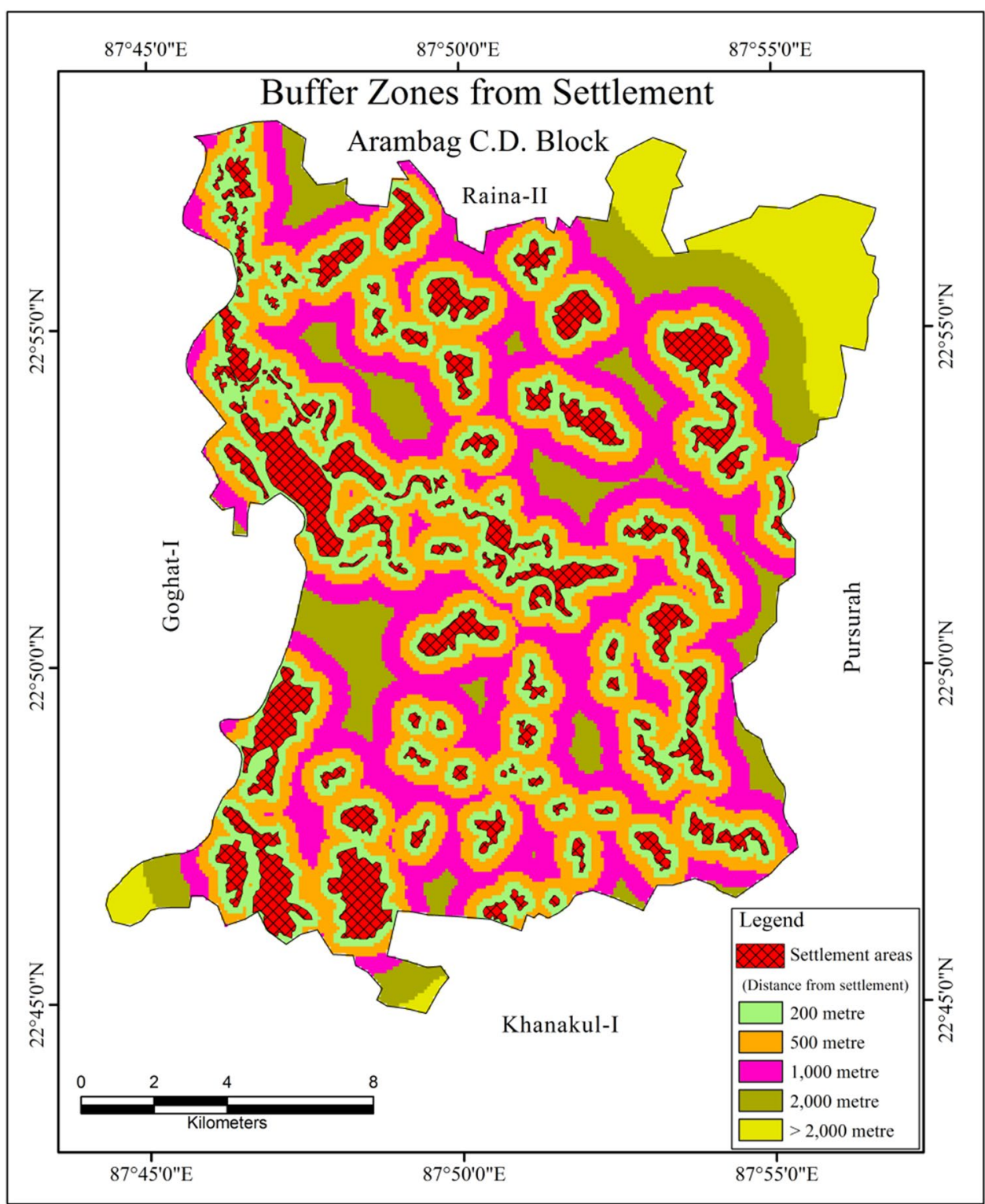

\begin{tabular}{llllllll}
\hline $\begin{array}{l}\text { Class (distance from } \\
\text { the settlement sites) }\end{array}$ & $200 \mathrm{~m}$ & $500 \mathrm{~m}$ & $1000 \mathrm{~m}$ & $2000 \mathrm{~m}$ & $>2000 \mathrm{~m}$ & Priority & Rank \\
\hline $200 \mathrm{~m}$ & 1.00 & 3.00 & 6.00 & 8.00 & 9.00 & 51.40 & 1 \\
$500 \mathrm{~m}$ & 0.33 & 1.00 & 4.00 & 6.00 & 8.00 & 27.70 & 2 \\
$1000 \mathrm{~m}$ & 0.17 & 0.25 & 1.00 & 4.00 & 7.00 & 12.80 & 3 \\
$2000 \mathrm{~m}$ & 0.12 & 0.17 & 0.25 & 1.00 & 3.00 & 5.20 & 4 \\
$>2000 \mathrm{~m}$ & 0.11 & 0.12 & 0.14 & 0.33 & 1.00 & 2.90 & 5 \\
\hline
\end{tabular}

Table 5 Pair-wise comparison matrix for prioritizing the buffer zones from settlement sites

\section{Conclusion}

Suitable locations for flood shelters have been identified for Arambag block through AHP and GIS applications. Proper site selection is necessary for successful 
Table 6 Pair-wise comparison matrix for calculating the priority of the themes

\begin{tabular}{lllllc}
\hline Theme & $\begin{array}{l}\text { Distance from inun- } \\
\text { dated zone }\end{array}$ & Elevation & $\begin{array}{l}\text { Accessibility to road } \\
\text { networks }\end{array}$ & $\begin{array}{l}\text { Proximity to settle- } \\
\text { ment sites }\end{array}$ \\
\hline Distance from inundated zone & 1.00 & 3.00 & 3.00 & 3.00 & 4 \\
Elevation & 0.33 & 1.00 & 2.00 & 3.00 & 2 \\
Accessibility to road networks & 0.33 & 0.50 & 1.00 & 0.50 & 25.70 \\
Proximity to settlement sites & 0.33 & 0.33 & 2.00 & 1.00 & 11.30 \\
\hline
\end{tabular}

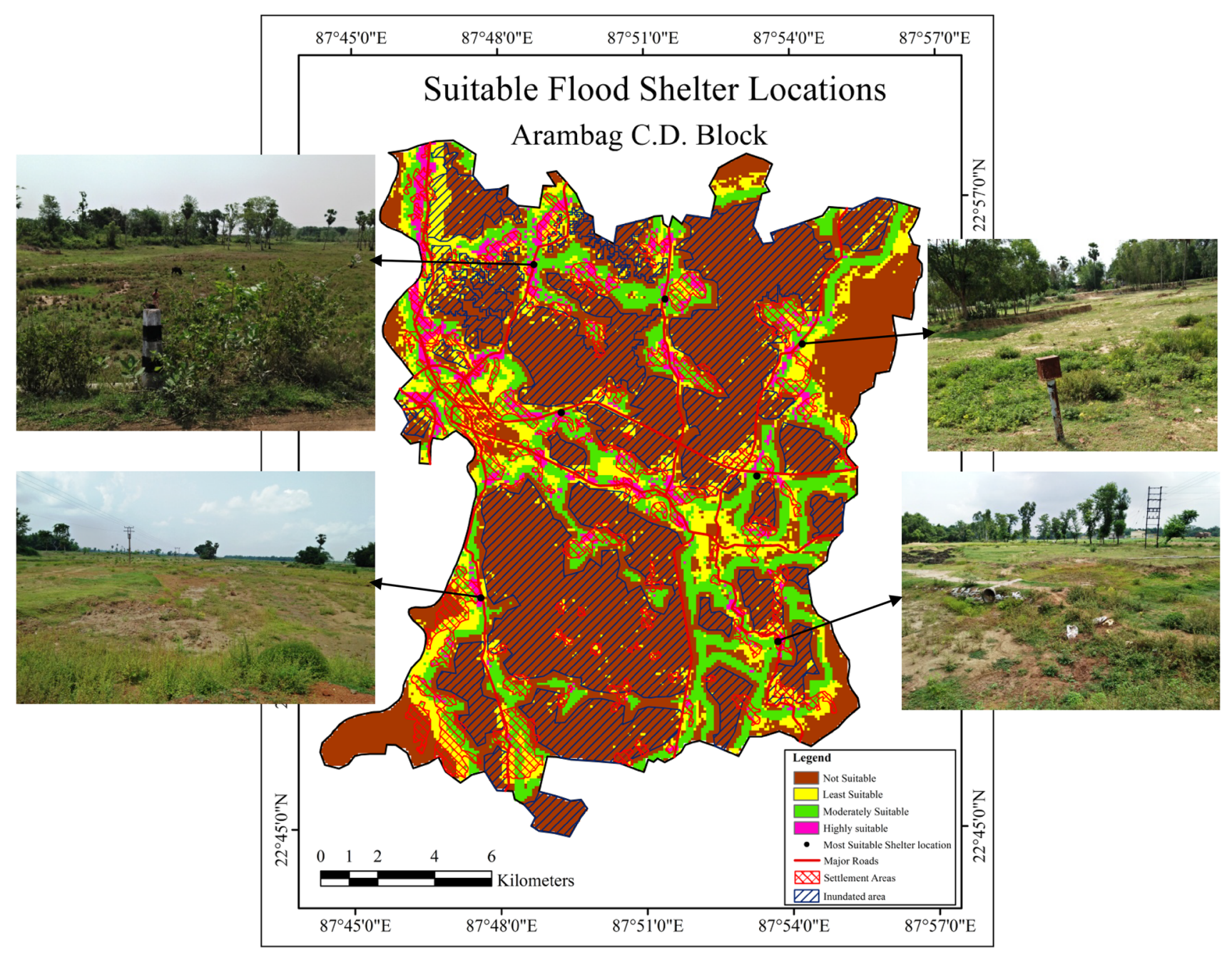

Fig. 7 Suitable locations for building flood shelters in the Arambag C.D. Block

mitigation of this type of flood hazard. Use of school, government buildings for evacuation shelters is not an ideal option for a flood prone area like this as the functions of these organizations are generally hampered for the relief activities. Construction of dual use temporary flood shelters is desired for the improvement of mitigation process which can benefit the society as a whole. Except the flood period, these dual use flood shelters can also be utilized as community halls for various ceremonies etc. which will generate revenue for the government in the long run. So planners should take proper actions in this respect to improve the situation of this region.

Acknowledgements The authors are grateful to the Department of Geography, The University of Burdwan for providing the infrastructural facilities. We are thankful to the different organizations like Google, Indian Space Research Organisation (ISRO) and United States Geological Survey (USGS) for providing useful data. We are 
thankful to the anonymous reviewers and editors for their valuable comments.

\section{Compliance with ethical standards}

Conflict of interest On behalf of all the authors, the corresponding author declares that there is no conflict of interest in this research article.

\section{References}

1. Sanyal J, Lu XX (2004) Application of remote sensing in flood management with special reference to monsoon Asia: a review. Nat Hazards 33:283-301

2. Mukhopadhyay S (2010) A geo-environmental assessment of flood dynamics in lower Ajoy River inducing sand splay problem in Eastern India. Ethiop J Environ Stud Manag 3:96-110

3. Mirza MMQ (2011) Climate change, flooding in South Asia and implications. Reg Environ Change 11:95-107

4. Ferreira S, Hamilton K, Vincent JR (2011) Nature, socioeconomics and adaptation to natural disasters: new evidence from floods. Policy research working paper. The World Bank, Washington, DC

5. Dewan A (2013) Floods in a megacity: geospatial techniques in assessing hazards, risk and vulnerability. Springer, Berlin

6. United Nations (2003) Guidelines for reducing flood losses. http://www.un.org/esa/sustdev/publications/flood_guidelines .pdf. Accessed 21 Sept 2018

7. Mallick DL, Rahman A, Alam M, Juel ASM, Ahmad AN, Alam SS (2005) Case study 3: Bangladesh floods in Bangladesh: a shift from disaster management towards disaster preparedness. IDS Bull 36:53-70

8. Kale VS (2014) Is flooding in South Asia getting worse and more frequent? Singap J Trop Geol 35:161-178

9. Nappi MML, Souza JC (2015) Disaster management: hierarchical structuring criteria for selection and location of temporary shelters. Nat Hazards 75:2421-2436

10. Sphere Project (2011) Humanitarian charter and minimum standards in humanitarian response. Practical Action Publishing, Rugby
11. Davis I (1978) Shelter after disaster. Oxford Polytechnic, Oxford

12. International Federation of Red Cross and Red Crescent Societies (2011) Transitional shelters: eight designs. International Federation of Red Cross and Red Crescent Societies, Geneva

13. Kar B, Hodgson ME (2008) A GIS-based model to determine site suitability of emergency evacuation shelters. Trans GIS $12: 227-248$

14. Apte $A$ (2009) Humanitarian logistics: a new field of research and action. Technol Inf Oper Manag 3:1-100

15. Saadatseresht M, Mansourian A, Taleai M (2009) Evacuation planning using multiobjective evolutionary optimization approach. Eur J Oper Res 198:305-314

16. Government of West Bengal (2015) Annual flood report 2015. Irrigation and Waterways Directorate, Government of West Bengal, Kolkata

17. Das B, Pal SC, Malik S (2018) Assessment of flood hazard in a riverine tract between Damodar and Dwarkeswar River, Hugli District, West Bengal, India. Spat Inf Res 26:91-101

18. Malczewski J, Rinner C (2015) Multicriteria decision analysis in geographic information science. Springer, Berlin

19. Saaty TL (1980) The analytic hierarchy process. McGraw-Hill, New York

20. Siddiqui MZ, Everett JW, Vieux BE (1996) Landfill siting using geographic information systems: a demonstration. J Environ Eng 122:515-523

21. Malczewski J (2006) GIS-based multicriteria decision analysis: a survey of the literature. Int J Geogr Inf Sci 20:703-726

22. Chandes J, Paché G (2010) Investigating humanitarian logistics issues: from operations management to strategic action. J Manuf Technol Manag 21:320-340

23. Omidvar B, Baradaran-Shoraka M, Nojavan M (2013) Temporary site selection and decision-making methods: a case study of Tehran, Iran. Disasters 37:536-553

Publisher's Note Springer Nature remains neutral with regard to jurisdictional claims in published maps and institutional affiliations. 